\title{
Indicators of Asian Achievement in Chemistry: Implications to the Philippine Setting
}

\author{
Joje Mar P. Sanchez* \\ College of Teacher Education, Cebu Normal University, Osmeña Boulevard, Cebu City 6000
}

\begin{abstract}
This paper aimed to determine the indicators, which could contribute to the Chemistry achievement of selected Asian countries according to the data set provided by the 2015 Trends in Mathematics and Science Survey results. Educational data mining was employed to capture patterns, comparison and correlation among selected Asian countries (Hong Kong, Japan, Malaysia, Singapore, South Korea, Taiwan and Thailand) using TIMSS results in Chemistry and other Science domains achievements, learning resources, school climate, instructional considerations, and student affective aspects. This study found out that the average Chemistry achievement of the Asian countries was significantly higher than the world achievement. Through exploratory analysis, it was revealed that high achievers among the Asian countries have moderate to high perspective towards school climate, instructional considerations and student affective aspects, while those average or low achievers had high perspective towards the said factors. The study concluded that, out of the 15 factors included in the study, nine had positive correlation yet only prior achievement in Science, home educational resources, Science laboratory resources, computer use and prevalence of bullying could significantly determine the achievement of learners in Chemistry. Implications on spiral progression, resource allocation, safe, orderly and harmonious environments, and inspiring stories in instruction were derived for application in the Philippine context to maximize and enhance learning in Chemistry.
\end{abstract}

Keywords: Asian achievement; Chemistry achievement; TIMSS

\section{INTRODUCTION}

Due to the fast growing development in scientific fields, Science education has become a priority across the globe due to it being a driving force of development (Chetty, 2012), and a fundamental key in solving issues in the global arena (Wieman, 2008). In fact, education ministries recognize the core importance of Science education in the curriculum (So and Cheng, 2009) where learners are prepared into becoming informed and participative citizens who can utilize and apply scientific principles and skills in solving problems in the 21st century society (Department of Education, 2016). As such, the learners are inculcated with scientific literacy and values. Organization of Economic and Co-operation and Development (2017) articulated that scientific literacy is shown in the ability of learners to be engaged in activities where they become reflective citizens. Scientific literacy, in this sense, can be measured as the Science achievement obtained by countries from international examinations such as Program for International Student Achievement (PISA) and Trends in Mathematics and Science Survey (TIMSS). The latter examination is the major achievement test for Math and Science in the primary and middle grade levels in the basic educational system (Scott, n.d.). Science framework for TIMSS highlights the assessment of the four main fields, namely Biology, Chemistry, Physics and 
Earth Sciences, and of the three cognitive domains, namely knowledge, application and reasoning.

TIMSS has shown many trends in Science education of the participating countries. The comparison between 2011 and 2015 results revealed that 15 out of the 34 participating countries have increased signfiicantly their achievement; 15 have neither increased nor decreased their achievements, and 4 have significantly decreased in their achievements (International Study Center, 2015). These, together with other trends, have shown to have implications to the educational systems of countries. Topçu et al. (2016), for instance, have found out that teacher effectiveness is a significant predictor of achievement, thus recommending education systems in Turkey and South Korea to invest in effective teaching practices in Science and Mathematics education fields. Perry (2017) analyzed the 2015 results of Northern Ireland, and recommended that the country's system further consider, among others, the involvement of teachers in continuing professional development, the decline in performance, and the principal's concerns around a lack of good quality school infrastructure like laboratories and computer rooms. Sumintono (2015) highlighted the drastic action of Malaysian education ministry to address the low achievement in Science of their learners through improvements in the curriculum, incorporating more problem-based and project-based content areas and cultivating high order thinking skills, which is targeted to be completed in 2017. Visser, Juan and Feza (2015) argued that educational system should not be contained solely in school level, pointing the needs of public interventions in other venues, especially the home environment where the learners originate. These are some studies generalizing the implications of TIMSS results to the policy-making for Science education improvement and paradigm shift, as well as building of public support for school improvements.

Contributory to the improvement of the Science education program of countries is the achievement obtained in Chemistry. Chemistry education is vital in knowledge generation and innovation, as efforts in Chemistry are shown in its functionality and relevance in content, practice and applicability (Emendu, 2014). Functionality of the field is exemplified in its applications in food security, agriculture, industries and transportation (Bhargava, 2016). Relevance of the field is seen in the pursuit of a sustainably developed society that takes into account ecological, economic and societal impacts (Eilks et al., 2014). This functional and relevant nature of Chemistry education make it fundamental in Science education, and thus, factors affecting education (i.e. teaching, learning and assessment) in Chemistry are important to be investigated. In fact, several studies in national and local levels were conducted to identify these factors, especially those that could indicate Chemistry achievement. Hassan et al., (2015) sampled 45 teachers and 200 students, and found out that teacher training, English language proficiency, and instructional facilities affected low achievement in Chemistry. Udoh (2012) and Oginni et al. (2013), studied learning environment and school factors as possible correlates, and revealed that school location, laboratory adequacy, practical class frequencey and home characteristics were positively correlated to Chemistry achievement. Moreover, Yüksel and Geban (2014) sampled 252 students, and found out that academic self-concept and logical thinking were significant predictors of academic achievment. Kan and Akbas (2006, 2007) investigated affective factors, and identified attitude, self-efficacy, motivation and anxiety as influences of Chemistry achievement. Furthermore, Tizo and Palmes (2013) showed that scholarship grants and Chemistry attitudes were significantly associated to Chemistry achievement, while Gutierrez (2014) identified students' ethnicity, and teachers' concern and encouragement as significant correlates to Chemistry achievement. Pedagogical studies conducted in the Philippines suggested that innovation teaching approaches and strategies such as career-oriented performance tasks (Espinosa et al., 2013), context-based teaching (Magwilang, 2016) and integrated macro-micro-symbolic approach (Sanchez, 2017) led to improved Chemistry achievement.

Though there are studies that investigate the association of factors to Chemistry achievement, there has been a gap in the read literature that deals with the big data provided by TIMSS. Trends and implications derived from TIMSS achievement and contexts results are important in improving the educational system, as well as developing paradigm shifts in curriculum development of countries, including the Philippines. In fact, the 2003 TIMSS results of the country had serious implications to the educational system, which may connote "bahala na" and "puwede na" culture towards Science and Chemistry as a subject and as an innovation (Dela Cruz, 2012), which eventually led to a change in the system to Revised Basic Education Curriculum. Since the Philippines is located in Asia, it is important to note that TIMSS results and trends in selected Asian countries may give insights and implications to how Chemistry education be implemented in the country. Therefore, the paper investigated the association between Asian achievement in Chemistry and several contexts derived from TIMSS. Specifically, the paper sought to (a) compare between Asian achievement and world achievement, as well as 
between Chemistry and other Science domains, and (b) determine the relationships between such achievement and contexts (learning resources, school climate, instructional considerations and affective considerations). The results of this paper were deemed useful, as these provide insights in improving Chemistry education in the country and the world at large, hence, the conduct of the study.

\section{METHODS}

The study utilized educational data mining (EDM) as this emerging design captures and creates pattern from big data sets that come from educational settings (Kumar and Vijayalakshimi, 2011). Through the use of EDM, comparison and correlation are done between and among seven participating countries found in Far East Asian region based on achievement and context results primarily from the 2015 TIMSS. The selected countries include Hong Kong (special administrative region in China), Japan, Malaysia, Singapore, South Korea, Taiwan (Chinese Taipei) and Thailand. These countries are chosen due to their geographic and cultural proximity to the Philippines.

The data involved in this study were mined from the databank of 2011 and 2015 TIMSS. Prior achievement of the participating countries in the fourth grade of 2011 TIMSS was used for comparison with the 2015 Chemistry achievement. Other than this, data on achievement and contexts were obtained from the 2015 TIMSS dataset. The context data (learning resources, school climate, instructional considerations and student affective aspects) were chosen since these may be possible correlates to Chemistry achievement based on literature review.

Table 1 below summarizes the TIMSS data used by the study. It is noted in the table that 2015 Chemistry achievement served as the baseline data for comparative and correlational analyses. A total of 15 possible factors or indicators were used in the study.

The data were treated with two analyses, namely t-test for small and single samples and Pearson $\mathrm{r}$ correlation test. The former ( $\mathrm{t}$-test) is used to compare the Chemistry achievement of the selected Asian countries to the achievement of Asia and the world. The latter (Pearson r) is used to determine the relationship between Chemistry achievement and context results. Moreover, analysis of variance is employed to compare the four Science domains. All tests are subjected to $\alpha=0.01$ for high significance, and $\alpha=0.10$ for partial significance.

Table 1. TIMSS Data Included in the Study.

\begin{tabular}{|c|c|c|c|}
\hline Year & Grade Level & Data Category & Possible indicators (as used in the study) \\
\hline \multicolumn{4}{|c|}{ Achievement Data } \\
\hline 2011 & 4 & Physical Science & (1) Prior achievement \\
\hline 2015 & 8 & $\begin{array}{l}\text { Science Domains: Chemistry } \\
\text { achievement \& other domains } \\
\text { achievements }\end{array}$ & \\
\hline \multicolumn{4}{|c|}{ Context Data } \\
\hline \multirow[t]{4}{*}{2015} & 8 & Learning Resources & $\begin{array}{l}\text { (2) Home resources } \\
\text { (3) Science lab } \\
\text { (4) Computer use } \\
\end{array}$ \\
\hline & & School Climate & $\begin{array}{l}\text { (5) Sense of belongingness } \\
\text { (6) School discipline } \\
\text { (7) Safety and order } \\
\text { (8) Student bullying }\end{array}$ \\
\hline & & Instructional Considerations & $\begin{array}{l}\text { (9) Instructional time } \\
\text { (10) Science investigations } \\
\text { (11) Effect of students' needs }\end{array}$ \\
\hline & & Student Affective Aspects & $\begin{array}{l}\text { (12) Engaging teaching } \\
\text { (13) Science liking } \\
\text { (14) Confidence } \\
\text { (15) Science valuing }\end{array}$ \\
\hline
\end{tabular}




\section{RESULTS AND DISCUSSION}

Chemistry Achievement of Selected Asian Countries. As seen in Table 2, leading economies in Asia, namely Hong Kong, Japan, Singapore, South Korea and Taiwan, had Chemistry achievements significantly higher than the world mean achievement. This means that the learners from these countries performed better than what is normally performed in the world. This could be due to the fact that these leading economic societies value education as a premium. In fact, these countries provided great effort in reshaping and reforming their Science curricula and school systems, including
Chemistry programs, in the past and recent years (Lau, 2014). Singapore, for instance, persisted in establishing Chemistry education back in the 1960s, involved local and international academic agencies in the process, and experienced several reforms in the program including the supplementation of basic education curriculum with out-of-school learning experiences such as industrial visits and scientific television programs (Chia, 2010). Collaboration among government agencies and partnerships with the private and international groups anchored reforms in Science education, thereby leading to improved curricula and enhanced student achievement (Malik, 2010).

Table 2. Chemistry Achievement of Selected Asian Countries.

\begin{tabular}{lllll}
\hline Country & Achievement & $\boldsymbol{t}$-value & p-value & Performance Level $^{\mathbf{a}}$ \\
\hline Hong Kong & 536 & $5.435^{* *}$ & 0.000 & Above Ave. \\
\hline Japan & 570 & $9.110^{* *}$ & 0.000 & Above Ave. \\
\hline Malaysia & 473 & $1.375^{\mathrm{ns}}$ & 0.177 & Average \\
\hline Singapore & 593 & $11.596^{* *}$ & 0.000 & Above Ave. \\
\hline South Korea & 550 & $6.948^{* *}$ & 0.000 & Above Ave. \\
\hline Taiwan & 579 & $10.083^{* *}$ & 0.000 & Above Ave. \\
\hline Thailand & 445 & $-4.401^{* *}$ & 0.000 & Below Ave. \\
\hline Average & 535 & $5.327^{* *}$ & 0.000 & Above Ave. \\
\hline Asian Achv. & 490 & World Achv. & 486 \\
\hline $\begin{array}{l}{ }^{2} \text { Performance level as compared to the world achievement at } 486 \\
{ }^{*} \text { Significant, }{ }^{n} \text { Not significant }\end{array}$ & &
\end{tabular}

On the other hand, Malaysia and Thailand had Average and Below Average achievements, respectively. Though investment in Science education in these countries covers a big portion of the national budget, the lower achievement might be due to the nature of teaching-learning process. Schools have paid more attention to lower-order thinking skills, have not integrated higher-order thinking skills in curriculum and assessment (Education for All National Review Report: Malaysia, 2015), and have employed strongly teacher-dominated pedagogy (Coll et al., 2014). To counteract such achievement, Malaysia is making drastic actions in improving Science education, including that of Chemistry, adapting challenges and trends in 21 st century education (Sumintono, 2015). Likewise, Thailand shifted the mindset of Thai students from being less active learners to more active participants in a learner-centered classroom using constructivistbased approach (Coll et al., 2014; Faikhamta and Ladachart, 2016).

The Philippines last took TIMSS in 2003, when the country got a Chemistry achievement of 342 while the world achievement mean was 474 . This indicated that the country had Below Average performance compared to the rest of the world. This Philippine result may be improved through following what high Asian achiever countries do, that is, to change the educational landscape of the country. This became a realization when the Philippines shifted its educational system from the congested and less advantageous system to the decongested and more competitive system called $\mathrm{K}$ to 12 Basic Education (Sergio, 2012), a similar initiative done by Singapore, Malaysia and Thailand (Lau, 2014; Sumintono, 2015; Coll et al., 2014). The paradigm shift provides comparable goals, content and duration to those given in leading country achievers (Sergio, 2012), as well as it offers facilitative approaches such as contextualized learning, inquiry-based approach and science-technology-society approach (DepEd, 2016), thereby improving Chemistry education in the country.

Asian Achievement of Chemistry vs. Other Science Domains. Chemistry achievement by the select Asian countries is not significantly different from the achievements obtained in Biology, Physics and Earth Science. This means that the Science 
achievements are comparable, inferring that these countries have curricular considerations in giving equal instructional time for these domains in their Science subjects. Japan, for example, covered the four Science fields in the 8th grade curriculum: electric currents (Physics), chemical changes, atoms and molecules (Chemistry), animal lives and living things transitions (Biology) and weather and its changes (Earth Science) (Ministry of Education, Culture, Sports, Science, and Technology, 2008). Giving consideration to ample time in teaching Science leads to a significant positive effect on student achievement (Lavy, 2010).

Table 3. Comparison between Chemistry and Other Science Domains in Selected Asian Countries.

\begin{tabular}{|c|c|c|c|c|c|c|}
\hline \multirow{2}{*}{ Country } & \multicolumn{4}{|c|}{ Achievements } & \multirow{2}{*}{ F-value } & \multirow{2}{*}{$P$-value } \\
\hline & Chem & Bio & Phys & Earth Sci & & \\
\hline Hong Kong & 536 & 549 & 540 & 558 & $0.0200^{\mathrm{ns}}$ & 0.9954 \\
\hline Japan & 570 & 570 & 570 & 574 & & \\
\hline Malaysia & 473 & 466 & 480 & 460 & & \\
\hline Singapore & 593 & 609 & 608 & 565 & & \\
\hline South Korea & 550 & 554 & 564 & 554 & & \\
\hline Taiwan & 579 & 565 & 560 & 581 & & \\
\hline Thailand & 536 & 549 & 540 & 558 & & \\
\hline
\end{tabular}

Another reason taken into consideration might be the interconnected approach in teaching Science concepts and principles, where one domain is used to explain other domains in the grade level or the next. This emphasis on interconnectedness is essential for the formulation of quality curricula, as well as the implementation of learning activities in the studentcentered classroom (Antonijević, 2006).

The comparable achievements among Chemistry and the other domains of Science may be taken into consideration by the paradigm shift system adopted by the basic education sector in the Philippines. The country's Science curriculum consists of the four domains of Science, namely Matter; Living Things \& their Environment; Force, Motion \& Energy; and Earth \& Space, which are all taught in every grade level in certain sequence similar to Japan's curriculum. Moreover, these four domains are presented in increasing level of complexity from one grade level to another in an approach called spiral progression (DepEd, 2016). Spiral progression in Science is considered learner-centered, sophisticated and advanced by Filipino Science teachers (Orbe et al., 2018), which was observed to be effective in teaching Science courses (Resurreccion and Adanza, 2015), and provided improved understanding with deepened learning among the students (de Ramos-Samala, 2018). Furthermore, due to the interconnectedness and spiral progression, aspiring Science teachers take a baccalaureate degree in Science rather than the specific Biological or Physical Sciences to suit themselves as teachers of the four areas of Science. Therefore, teachers's knowledge, skills and values should be developed further to implement Science education, especially Chemistry education: an instruction that is dynamic, realistic and productive (Orbe et al., 2018). As such, qualified teachers and well-suited facilities should be present.

Chemistry Achievement and Prior Achievement in Science. Based on Table 4, there is a highly significant difference between the 2011 Physical Science achievement and 2015 Chemistry achievement gotten by the Asian countries. This means that the learners' achievement when they were still in 4th grade had a positive impact to their achievement in Grade 8. This could be due to the fact that prior achievement motivated the learners to attain higher achievement in the future. Prior achievement can significantly predict student engagement, thereby leading to positive association to the further achievements ( $\mathrm{Li}$ et al., 2017), as achieved knowledge could be developed over time (Claro et al., 2016).

In coherence with spiral progression, prior achievement plays an important role. Prior achievement connotes prior knowledge, previous experiences and preparatory skills, which are needed in the understanding of concepts in the present. Therefore, vertical articulation becomes an essential characteristic of a good spirally progressive Science curriculum (de Ramos-Samala, 2018). This suggests that Science teaching in the elementary level should introduce the basic Chemistry concepts and skills, which are taught by Filipino teachers in spiral progression, so that learners will be equipped with 
Table 4. Association between 2015 Chemistry and 2011 Physical Science Achievements.

\begin{tabular}{lcccc}
\hline \multirow{2}{*}{ Country } & \multicolumn{2}{c}{ Achievement } & \multirow{2}{*}{-value } & \multirow{2}{*}{ p-value } \\
\cline { 2 - 3 } & Chem (2015) & Phys Sci (2011) & & \\
\hline Hong Kong & 536 & 539 & $0.9307^{* *}$ & 0.0070 \\
\hline Japan & 570 & 589 & & \\
\hline Malaysia & 473 & - & & \\
\hline Singapore & 593 & 598 & & \\
\hline South Korea & 550 & 597 & & \\
\hline Taiwan & 579 & 569 & & \\
\hline Thailand & 536 & - & & \\
\hline "Highly significant & & & & \\
- Not taken the 2011 Grade 4 TIMMS & & & & \\
\hline
\end{tabular}

the foundations essential for high school Chemistry concepts. In turn, high school teaching should include review phase in their lesson implementation to establish a link between the learners' prior knowledge to the present topic.

Learning Resources. The Chemistry achievement of Asian countries had a significant association with that of the home education resources. This suggests that the availability of educational resources, such as books, computers, calculators and study tables in the learners' homes provided them more means to use these for studying and learning concepts in Chemistry. Parents buy these available resources at home in order to encourage active and independent learning, which could most likely increase participation and interest in school (Spelling, 2005). Home works utilizing such resources provide opportunities for applying and deepening of the understanding of concepts (Ontario English Catholic Teachers' Association, 2016). Home environment resources play important roles in learners' achievement in Science in general (Juan and Visser, 2017; Oginni et al., 2013).

Also revealed in the table is the positive and significant association of the Science laboratory resources to the Chemistry achievement of the learners. In this regard, laboratories provide a venue for learners to apply the chemical concepts and processes through the hands-on-minds-on activities, including experimentations. Hong Kong, in particular, has laboratories for all schools since the Junior Secondary Science Curriculum was implemented in 2000. This curriculum embeds investigative approach in teaching which involves learners to identify problems, create designs for solutions, do practical work and use analysis in interpreting results. The

Table 5. Correlation between Chemistry Achievement and Achievement by Learning Resources.

\begin{tabular}{|c|c|c|c|c|}
\hline Country & Achievement $^{\mathrm{a}}$ & Home Resources $^{\text {b }}$ & Science Lab ${ }^{c}$ & Computer Used $^{\mathrm{d}}$ \\
\hline Hong Kong & 1.10 & 1.07 & 1.11 & 1.13 \\
\hline Japan & 1.17 & 1.12 & 1.17 & 1.16 \\
\hline Malaysia & 0.97 & 0.99 & 0.96 & 1.00 \\
\hline Singapore & 1.22 & 1.20 & 1.22 & 1.20 \\
\hline South Korea & 1.13 & 1.07 & 1.14 & 1.12 \\
\hline Taiwan & 1.19 & 1.14 & 1.17 & 1.16 \\
\hline Thailand & 0.92 & 1.01 & 0.93 & 0.95 \\
\hline Average & 1.10 & 1.08 & 1.10 & 1.12 \\
\hline \multirow[t]{2}{*}{ Statistics } & r-value & $0.927^{* *}$ & $0.995^{* *}$ & $0.989^{* *}$ \\
\hline & $\mathrm{p}$-value & 0.003 & 0.000 & 0.000 \\
\hline
\end{tabular}

${ }^{a}$ Country over world achievement ratio

b "Most Resources" achievement ratio

c "With Science Laboratory" achievement ratio

d "With Computer" achievement ratio

${ }^{* *}$ Highly significant 
science laboratory promotes important meaningful learning outcomes for learners (Hofstein, 2004; Oginni et al., 2013), thus is a determinant of high achievement in Chemistry.

Same with home education and Science laboratory resources, computer use had positive and significant relationship with the Chemistry achievement of learners. This may be due to the utilization of computer as a venue of multiple media where learners could understand chemical concepts and processes in a more multisensorial means. Due to this multisensorial nature of computers, these tools are used to motivate and activate learners, thereby creating an avenue for creative thinking and critical understanding of Science, particularly to Chemistry (Lanoven, 2008). Instructional tasks, which involve computer use provide different ways of expressing knowledge, therefore have positive impact to student achievement (Sun and Bradley, n.d.).

Overall, Chemistry achievement is positively and significantly correlated with the availability and access of learning resources at home and in the school. However, these learning resources essential for learning and teaching are lacking in Filipino homes and schools. Philippine Statistics Authority (2017) reported that only a very small portion, at $2.3 \%$ to $4.0 \%$, of the income of the masses are spent to education and educational resources, suggesting a lack of resources at home. Agham columnist Marbella (2014) wrote that DepEd reported a lack of science laboratories in public elementary amd secondary schools, as well as a inadequacy of modern equipment in schools with laboratories, indicating a dearth in venues where students do Chemistry experimentations. Case studies on ICT in the Philippines conducted by Kubota et al., (2016) revealed that there is limited number of compuuters and no Internet connection in rural and suburban areas, showing a lack of computer facilities in schools. The learning resources that learners from among the masses lack are important tools in Chemistry education. Therefore, allocation for these learning resources for schools should be given emphasis in the planning of budget for the education sector. In particular, Science laboratories should be built in every school in order to provide venues for hands-on, minds-on tasks using the investigative approach. Equally important is the decrease of the students-to-computer use ratio, so as to offer more independent work among the students and to give them opportunity to discover Chemistry, and the Sciences, secondhand but enriched.

School Climate. The environment where the learners are plays an important role in the achievement of students. Four variables were statistically analyzed, and found out that sense of belongingness had significant negative correlation with student achievement, while school discipline and safety and order did not have a significant association. This could mean that high achieving countries tend to have learners who do not feel high sense of belongingness in school. This could be due to the overly structured environment of the Asian schools, which give premium to education, and thus have more demands expected from them. Due to this demand, learners may have negative feelings towards the school that they think they do not belong (Ho,

Table 6. Correlation between Students' Chemistry Achievement and the School Climate.

\begin{tabular}{|c|c|c|c|c|c|c|c|c|c|}
\hline \multirow{2}{*}{$\begin{array}{l}\text { Country } \\
\text { Hong Kong }\end{array}$} & \multirow{2}{*}{$\begin{array}{c}\text { Achievement }^{\mathbf{a}} \\
\mathrm{AA}\end{array}$} & \multicolumn{2}{|c|}{$\begin{array}{c}\text { Sense of } \\
\text { Belongingness }^{b}\end{array}$} & \multicolumn{2}{|c|}{$\begin{array}{c}\text { School } \\
\text { Discipline }^{c}\end{array}$} & \multicolumn{2}{|c|}{$\begin{array}{c}\text { Safety and } \\
\text { Order }^{d}\end{array}$} & \multicolumn{2}{|c|}{$\begin{array}{l}\text { Student } \\
\text { Bullying }\end{array}$} \\
\hline & & 9.4 & $S$ & 11.4 & $\mathrm{H}$ & 10.7 & VSO & 9.6 & $\mathrm{~N}$ \\
\hline Japan & $\mathrm{AA}$ & 9.4 & $S$ & 10.5 & $\mathrm{M}$ & 8.9 & SO & 10.9 & $\mathrm{~N}$ \\
\hline Malaysia & A & 10.1 & $S$ & 10.8 & $\mathrm{H}$ & 9.8 & SO & 9.3 & $\mathrm{~N}$ \\
\hline Singapore & $\mathrm{AA}$ & 9.8 & $S$ & 11.7 & $\mathrm{H}$ & 11.3 & $\mathrm{VSO}$ & 9.7 & $\mathrm{~N}$ \\
\hline South Korea & $\mathrm{AA}$ & 9.4 & $S$ & 11.0 & $\mathrm{H}$ & 9.8 & $\mathrm{SO}$ & 11.1 & $\mathrm{~N}$ \\
\hline Taiwan & $\mathrm{AA}$ & 9.4 & $S$ & 11.1 & $\mathrm{H}$ & 10.1 & $\mathrm{SO}$ & 11.3 & $\mathrm{~N}$ \\
\hline Thailand & $\mathrm{BA}$ & 10.6 & HS & 10.4 & $\mathrm{M}$ & 10.1 & $\mathrm{SO}$ & 8.8 & $\mathrm{M}$ \\
\hline Average & $\mathrm{AA}$ & 9.7 & $S$ & 11.0 & $\mathrm{H}$ & 10.1 & $\mathrm{SO}$ & 13.7 & $\mathrm{~N}$ \\
\hline Statistics & $\begin{array}{l}\text { r-value } \\
\text { p-value }\end{array}$ & \multicolumn{2}{|c|}{$-0.814^{*}$} & \multicolumn{2}{|c|}{$0.603^{\text {ns }}$} & \multicolumn{2}{|c|}{$0.167^{\text {ns }}$} & \multicolumn{2}{|c|}{$0.723^{*}$} \\
\hline
\end{tabular}

${ }^{a}$ AA (Above average), A (Average), BA (Below average)

${ }^{\mathrm{b}} \mathrm{HS}$ (High sense of belongingness), S (Average sense), L (Low sense)

${ }^{c} \mathrm{H}$ (Hardly any problems), M (minor problems), MS (moderate to severe)

d VSO (Very safe and orderly), SO (Average safe and orderly), LSO (Less safe and orderly)

${ }^{\mathrm{e}} \mathrm{N}$ (Almost never occuring), M (About monthly), W (About weekly)

Partially significant, ${ }^{\text {ns }}$ Not significant 
2009). Despite this negativity, they work efficiently in school, thereby having higher achievement.

School discipline and safety and order in school had no significant relationship with the student achievement. This means that problems on school discipline and the extent of the school safety and order do not have impact on Chemistry achievement despite studying in a highly disciplined environment. Japan, for example, has a big problem on disciplinary issues, such as classroom violence towards teachers and learners, which did not obstruct their high achievement in mathematics and sciences. School disciplinary and safe environment do not directly influence student learning attainment (Ishida and Miwa, 2012).

Less bullying experienced by the learners had a partially significant association with their achievement in Chemistry. This means that when students are not, or less threatened by bullying inside the school, they tend to perform better and achieve higher achievement. No or less bullying creates a positive atmosphere where learners feel safe inside the classroom, thus they are not hindered to attain academic success in themselves (Block, 2014).

Though the results of most school climate factors were not significantly associated with Chemistry achievement, it is also good to note that having a conducive and sensitive learning environment could boost achievement in the learners' academics. In fact, a study by Gorgonio (2017) found out that learners' belongingness in school is central in quality relationships between students and personnel, where teaching and learning process becomes relational and productive. Moreover, an investigation by Magulod (2017) revealed that there is a significant association between school performance and school effectiveness factors including safe and orderly environment for learners. Furthermore, a qualitative study by Gabiana (2017) stated that bullying could lead to dropouts and decreased achievement, and that less of bullying creates positive environment where they are not hindered to attain academic success, including in Chemistry (Block, 2014). The results of the abovementioned Filipino studies imply that schools should provide positive discipline in order to create a safe, orderly and harmonious environment where learners cooperate and value the tasks there are immersed in. Interesting lessons and purposive learning experiences should be employed to the class, in order to provide conducive, relevant and meaningful learning environment.

Instructional Considerations. Based on Table 7, instructional time and effect of limited teaching due to students' needs do not significantly affect Asian countries achievement in Chemistry. Time and students' needs do not drive the academic performance for better achievement due to the fact that these factors are not unusually changed within the span of the instructional year. Due to these insignificant changes, instructional time and students' needs are not considered as indicators for academic success (Baker et al., 2004).

On the other note, the science investigations have significantly yet negatively associated to the Chemistry achievement of the learners. This means

Table 7. Correlation between Students' Chemistry Achievement and Instructional Considerations.

\begin{tabular}{|c|c|c|c|c|c|c|}
\hline \multirow{2}{*}{$\begin{array}{l}\text { Country } \\
\text { Hong Kong }\end{array}$} & \multirow{2}{*}{$\begin{array}{c}\text { Achievement }^{\mathbf{a}} \\
\mathrm{AA}\end{array}$} & \multirow{2}{*}{$\begin{array}{c}\text { Instructional Time }^{\mathbf{b}} \\
102\end{array}$} & \multicolumn{2}{|c|}{$\begin{array}{c}\text { Science } \\
\text { Investigations }^{\mathrm{c}}\end{array}$} & \multicolumn{2}{|c|}{$\begin{array}{c}\text { Effect of Students } \\
\text { Needs }{ }^{d}\end{array}$} \\
\hline & & & 10.1 & $\mathrm{LH}$ & 10.6 & SL \\
\hline Japan & $\mathrm{AA}$ & 131 & 9.9 & $\mathrm{LH}$ & 12.5 & NL \\
\hline Malaysia & $\mathrm{A}$ & 130 & 10.4 & $\mathrm{LH}$ & 9.8 & SL \\
\hline Singapore & AA & 106 & 9 & $\mathrm{LH}$ & 11 & SL \\
\hline South Korea & AA & 94 & 9.3 & $\mathrm{LH}$ & 9.8 & SL \\
\hline Taiwan & AA & 144 & 8.9 & $\mathrm{LH}$ & 10 & SL \\
\hline Thailand & $\mathrm{BA}$ & 110 & 10.1 & $\mathrm{LH}$ & 10 & SL \\
\hline Average & AA & 116.7 & 9.7 & $\mathrm{LH}$ & 10.5 & SL \\
\hline Statistics & $\begin{array}{l}\text { r-value } \\
\text { p-value }\end{array}$ & $\begin{array}{c}0.082^{\text {ns }} \\
0.861 \\
\end{array}$ & \multicolumn{2}{|c|}{$\begin{array}{c}-0.770^{*} \\
0.043\end{array}$} & \multicolumn{2}{|c|}{$\begin{array}{l}0.473^{\mathrm{ns}} \\
0.283\end{array}$} \\
\hline
\end{tabular}

${ }^{a}$ AA (Above average), A (Average), BA (Below average)

${ }^{b}$ Instructional time presented in hours per year

c Time for Science investigations, UH (upper or half of the lesson), LW (lower half)

${ }^{\mathrm{d}}$ NL (Not limited), SL (Somewhat limited), VL (Very limited)

* Partially significant, ${ }^{\text {ns }}$ Not significant 
that though the teachers have limited utilization of the eight instructional tasks, the learners still have higher achievement. Better learning is not enclosed in one structured approach but is determined by the appropriateness of the pedagogy in teaching topics in Chemistry (Ganyaupfu, 2013).

In the $\mathrm{K}$ to 12 basic education system of the Philippines, Chemistry and other Science domains are given equal time allotment (i.e. one grading period each). Increasing or decreasing instructional time could imply an imbalance in the teaching of Science areas, which will disrupt the teachinglearning process aslearners track the spiral progression approach in Science. Moreover, the use of a structured set of recommended pedagogies may not adhere with the implementation of the Science curriculum because pedagogies should be contextualized to the needs of the learners, where a repertoire of pedagogies may be used such as problem-solving approach, science-technology-society approach and inquiry-based approach. Learners may benefit from contextualized lesson implementation rather than following structured pedagogies because they will be engaged in varied minds-on, hands-on and heartson activities centered on situations that challenge the learners to be critical and creative thinkers (Department of Education, 2016). Furthermore, students' needs may not give significant effect, as the curriculum provides mechanisms to provide instruction according to the needs of the learners. Therefore, the use of 21 st century pedagogies as well as innovative teaching such as s career-oriented performance tasks (Espinosa et al., 2013), context- based teaching (Magwilang, 2016) and integrated macro-micro-symbolic approach (Sanchez, 2017) lead to meaningful understanding of Chemistry and to relevant applications in the students' life.

Affective Considerations. Three student affective aspects have insignificant association with student achievement. These are students' views on engaging teaching, science interest and confidence. This means that when learners view Chemistry teaching as engaging and interesting, better achievement does not always happen. Learners may be imbued more of the process of the activity but not the understanding of the lesson, or they are more interested on other Science topics but not Chemistry topics. These situations characterize that engagement, interest and confidence towards the subject do not lead to successful academic endeavor. It is in the hardwork that the learners give when immersed with the instructional activities (Sjöberg and Dahlstrand, 1987).

As exposed in Table 8, science valuing and achievement had partially significant negative association. This means that, in some ways, achievement decreases as science valuing increases. However, this negative association may be because of the lack of learning resources, which hinders student academic performance even if learners have high valuing towards the sciences. Take Thailand as an example. Though Thai government introduced 15 -year free education policy in 2009, many learners could not afford the cost of other educational expenses, like learning materials, due to financial

Table 8. Comparison of Students' Chemistry Achievement and the Affective Considerations.

\begin{tabular}{lccccccccc}
\hline Country & Achievement $^{\mathbf{a}}$ & \multicolumn{2}{c}{$\begin{array}{c}\text { Engaging } \\
\text { Teaching }\end{array}$} & Science Liking & & \multicolumn{2}{c}{ Confidence $^{\mathbf{d}}$} & \multicolumn{2}{c}{ Science Valuing $^{\mathbf{e}}$} \\
\hline Hong Kong & AA & 9.6 & E & 9.9 & L & 9.4 & C & 9.4 & V \\
\hline Japan & AA & 8.4 & E & 9 & L & 8.6 & NC & 8.6 & V \\
\hline Malaysia & A & 10.2 & VE & 10.9 & VL & 8.7 & NC & 10.4 & V \\
\hline Singapore & AA & 9.8 & E & 10.3 & L & 9.7 & C & 10.2 & V \\
\hline South Korea & AA & 8.4 & E & 8.6 & L & 8.7 & NC & 9 & V \\
\hline Taiwan & AA & 9 & E & 9.2 & L & 8.6 & NC & 8.6 & V \\
\hline Thailand & BA & 10.2 & VE & 10.3 & L & 9.3 & C & 10.7 & SV \\
\hline Average & AA & 9.4 & E & 9.7 & L & 9.0 & C & 9.6 & V \\
\hline Statistics & r-value & $-0.636^{\text {ns }}$ & $-0.563^{\text {ns }}$ & $-0.023^{\text {ns }}$ & $-0.689^{*}$ \\
& p-value & 0.125 & 0.189 & 0.961 & 0.087 \\
\hline
\end{tabular}

${ }^{a}$ AA (Above average), A (Average), BA (Below average)

${ }^{b} \mathrm{VE}$ (Very engaging), E (Engaging), LE (Less engaging)

c VL (Very much like), L (Like), DL (Do not like)

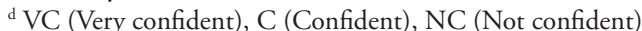

e SV (Strongly value), V (Value on average), DV (Do not value)

"Partially significant, ${ }^{\text {ns }}$ Not significant 
difficulties (OECD, 2013).

Affective aspects provide the heart of learners in the teaching and learning process. As such, extent of learners' considerations on these aspects is a set of important factors that could affect achievement in Chemistry. As such, the affective domain of the learners should be developed, not only in receiving tasks but also in characterization processes. In this regard, encourage learners to value and love Sciences in general in order to spark their curiosity. As such, Chemistry instruction should include inspiring stories of Science people.

\section{CONCLUSIONS}

Chemistry achievement in neighboring countries of the Philippines had higher achievement levels, in average than the world, attributing this primarily of the 'premium' that they give to education. High achievers among Asian countries have moderate to high perspective towards school climate, instructional considerations and student affective aspects, while those average or low achievers had high perspective towards the said factors. Specifically, Chemistry achievement was positively and significantly associated with students' prior achievement in Science, which could imply that spiral progression in Science curriculum could provide effective delivery and implementation of the science concepts and skills. Chemistry achievement also had positive and significant correlation with home educational resources, Science laboratory resources, and computer use, which means that availability of and accessibility to references, science experiments, online search, particulate animations, and theoretical simulations are essential to improved Chemistry instruction as well as enhanced critical and creative thinking. Prevalence of bullying also had positive and significant association with achievement, which signify the creation of a safe and orderly environment among the learners themselves. Lastly, Science valuing had negative yet significant correlation with achievement, which indicates costs and lack of resources as hindrance to achieve more despite of students' high extent of valuing.

Based on the findings of the study, the researcher recommended that spiral progression be continued to be employed across Science curricula; that laboratory-to-student ratio be decreased in order to increase extent of practical skills of students; that positive discipline be always observed in the learning environment; and that characterization processes be implemented to spark curiosity and appreciation towards Chemistry and Science in general. Future researchers may conduct similar educational data mining research for other domains of Science, as well as for Chemistry achievement and contexts which will be derived from the upcoming 2019 TIMSS results and trends.

\section{REFERENCES}

Antonijević R. Conceptual connections in teaching of technical education and physics [Internet]. 2006. Available from http://files.eric.ed.gov/fulltext/ ED497738.pdf

Baker D, Fabrega R, Galindo C, Mishook J. Instructional time and national achievement: Crossnational evidence. Prospects. 2004; 34 (3), 311-334

Bhargava PM. Scientific research and economic development. Social Change. 2016. DOI: $10.1177 / 0049085716635403$

Block N. The impact of bullying on academic success for students with and without exceptionalities [Internet]. 2014. Available from https://tspace. library.utoronto.ca/bitstream/1807/67006/1/Block _Nadine_F_201406_MT_MTRP.pdf

Chetty L. The role of science and technology in the developing world in the 21st century. Institute for Ethics and Emerging Technologies [Internet]. 2012. Available from https://ieet.org/index.php/IEET2/ more/chetty 20121003

Chia L. Chemical education in Singapore. Chemical education in Asia-Pacific [Internet]. 2010. Available from http://www.t.soka.ac.jp/chem/CEAP/ Singapore.html

Claro S, Paunesku D, Dweck C. Growth mindset tempers the effects of poverty on academic achievement. Proceedings of the National Academy of Sciences of the United States of America. 2016; 113(31): 8664-8668. doi: 10.1073/ pnas. 1608207113

Coll R, Dahsah C, Chairam S, Jansoon N. Fostering active Chemistry learning in Thailand: Toward a learner-centered student experiences. In: Devetak, I. and Glažar, S. (Eds.) Learning with understanding in the Chemistry classroom. Springer: Dordrecht; 2014

de Ramos-Samala H. Spiral progression approach in teaching Science: A case study. 4th International Research Conference on Higher Education. 2018; 555-567. DOI: 10.18502/kss.v3i6.2404

dela Cruz RS. The science dilemma in Philippine schools[Internet]. Availablefromhttp://www.science. ph/full_story.php?type $=$ News $\&$ key $=6602$ : the- 
science-dilemma-in-\%20philippine-schools

Department of Education. $\mathrm{K}$ to 12 curriculum guide: SCIENCE (grades 3 to 10) [Internet]. 2016. Available from http://www.deped.gov.ph/ wp-content/uploads/2019/01/Science-CG_withtagged-sci-equipment_revised.pdf

Education for All 2015 National Review: Malaysia [Internet]. 2015. Available from http://unesdoc. unesco.org/images/0022/002297/229719E.pdf

Eilks I, Sjöström J, Hofstein A. Relevant Chemistry education for sustainability. In: Eilks, I, Markic, S, Ralle, B (Eds.) Science eduaction research and education for sustainable development. Aachen: Shaker.

Emendu NB. The role of Chemistry education in national development. Int J Eng Sci. 2014; 3 (3), 12-17

Espinosa, AA, Monterola, SLC, Punzalan, AE. Career-oriented performance tasks in Chemistry: Effects on students' critical thinking skills. Educ Res Int. 2013. DOI: 10.1155/2013/834584

Faikhamta C, Ladachart L. Science education in Thailand: Moving through crisis to opportunity. In: Chiu, M. (Ed.) Science education research and practice in Asia. Springer : Singapore; 2016

Gabiana MG. Bullying in a public elementary school of countryside Philippines. J Acad Res. 2017; 2 (1), 27-35

Ganyaupfu E.. Teaching methods and students' academic performance. Int J Hum Soc Sci. 2013; 2 (9), 29-35

Garcia AS. Parental involvement among lowincome Filipinos: A phenomenological inquiry [dissertation]. [Lincoln]. University of Nebraska. 2018, 145 p.

Gorgonio JPR. School climate determinants: Perception and implications. Asia-Pac J Educ Arts Sci. 2017; 4 (2), 31-37

Gutierrez RLV. Determinants of Chemistry performance of teacher education students of state colleges and universities in Cagayan Valley. Int Conf Econ Educ Hum. Bali, Indonesia; Dec. 10-11, 2014. DOI: 10.15242/ICEHM.ED1214151

Hassan AA, Ali HI, Salum AA, Kassim AM, Elmoge YN, Amour AA. Factors affecting students' performance in Chemistry: Case study in Zanzibar secondary schools. Int J Soc Behav Educ Econ Bus Ind Eng. 2015; 9 (11), 4016-4023

Ho E. Characteristics of East Asian learners: What we learned from PISA. Educ Res J. 2009; 24 (2), 327-348

Hofstein A. The laboratory in Chemistry education: Thirty years of experience with developments, implementation, and research. Chem Educ Res Prac. 2004; 5(3):247-264

International Study Center. Student achievement overview: Grade 8 [Internet]. 2015. Available from http://timssandpirls.bc.edu/timss2015/ international-results/timss-2015/science/studentachievement/

Ishida H, Miwa S. School discipline and academic achievement in Japan. In: Arum R, Velez M. (Eds.) Improving learning environments: School discipline and student achievement in comparative perspective. 2012

Juan A, Visser M. Home and school environmental determinants of science achievement of South African students. South Afr J Educ. 2017; 37(1):110, doi: 10.15700/saje.v37/n1a1292

Kan A, Akbas A. Affective factors that influence Chemistry achievemetn (attitude and self-efficacy) and the power of these factors to predict Chemistry achievement. J Turk Sci Educ. 2006; 3 (1), 76-85

Kan A, Akbas A. Affective factors that influence Chemistry achievement (motivation and anxiety) and the power of these factors to predict Chemistry achievement-II. 2007; 4 (1), 10-19

Kubota K, Yamamoto R, Morioka H. Promoting ICT education in developing countries: Case study in the Philippines [Internet]. Retrieved from https:// www.researchgate.net/publication/228655099_ Promoting_ICT_education_in_developing_ countries_Case_Study_in_the_Philippine

Kumar SA, Vijayalakshimi M. A novel approach in data mining techniques for educational data. 3rd Int Conf Mach Learn Comput. 2011

Lanoven J. Learning and the use of ICT in Science education. Effective use of ICTin Science education [Internet]. 2008. Retrieved from https://www.fizyka. umk.pl/ $\sim$ pdf/EU_ISE/files/new/EUISEBook-HR. pdf

Lau K. The science education of the East Asian regions - what we can learn from PISA. Asia-Pacific 
Forum on Science Learning and Teaching. 2014.15 (2), $1-18$

Lavy V. Do differences in school's instruction time explain international achievement gaps? Evidence from developed and developing countries. National Bureau of Economic Research. 2010. Retrieved from http://www.nber.org/papers/w16227.pdf

Li P, Zhou N, Zhang Y, Xiong Q, Nie R. and Fang $\mathrm{X}$. Incremental theory of intelligence moderated the relationship between prior achievement and school engagement in Chinese high school students. Frontiers in Psychology. 2017; 8:1703. doi: 10.3389/ fpsyg.2017.01703

Magulod GC. Factors of school effectiveness and performance of selected public and private elementary schools: Implications on educational planning in the Philippines. Asia-Pac J Multidiscip Res. 2017; 5 (1), 73-83

Magwilang EB. Teaching Chemistry in context: Its effects on students' motivation, attitudes and achievement in Chemistry. Int J Learn Teach Educ Res. 2016; 15 (4), 60-68

Malik A. Public-private partnerships in education: lessons learned from the Punjab education foundation. Asian Development Bank : Mandaluyong City; 2010

Marbella R. Science education realities [Internet]. Available from https://www.manilatimes.net/ science-education-realities/100096/

Ministry of Education, Culture, Sports, Science, and Technology Guidelines for teaching junior high school (English version) Internet version [2008]. Available from http://www.mext.go.jp/a_me-nu/ shotou/newcs/youryou/eiyaku/1298356.htm

Oginni AM, Awobodu VY, Alaka MO, Saibu SO. School factors as correlates of students' achievement in Chemistry. Int J Crossdiscip Subj Educ. 2013; 3 (3), 1516-1523

Orbe JR, Espinosa AA, Datukan JT. Teaching Chemistry in a spiral progression approach: Lessons from Science teachers in the Philippines. Aust J Teach Educ. 2018; 43 (4), 17-30

Organization for Economic Co-operation and Development. Southeast Asian economic outlook 2013 [Internet]. 2013. Available from http://www. oecd-ilibrary.org/development/southeast-asianeconomic-outlook-2013_saeo-2013-en
OECD. PISA for development brief [Internet]. 2017. Available from https://www.oecd.org/pisa/ pi-sa-for-development/10-How-PISA-D-mea-suresscience-literacy.pdf

Ontario English Catholic Teachers' Association. Encouraging Math learning at home: A guide for parents [Internet]. 2016. Retrieved http:// www.catholicteachers.ca/OECTA/media/pdfs/ Parental\%20Resour-ces/math_resource_for_ parents.pdf

Perry C. TIMSS and PISA. Research and Information Service briefing note [Internet]. 2017. Available from http://www.niassembly.gov.uk/globalassets/ documents/raise/publications/20162021/2017/ education/0317.pdf

Philippine Statistics Authority. 2017 Family income and expenditure survey [Internet]. Available from https://psa.gov.ph/sites/default/files/FIES\%20 2015\%20Final\%20Report.pdf

Resurrecion JE, Adanza J. Spiral progression approach in teaching Science in selected private and public schools in Cavite. Proceedings of the DLSU Research Congress. 2015; 3:1-12. Available from http://www.dlsu.edu.ph/conferences/dlsu_ research_congress/2015/proceedings/LLI/017LLI_ Resurrecion_GF.pdf

Sanchez JM. Integrated macro-micro-symbolic approach in teaching secondary Chemistry. Kimika. 2017; 28 (2), 22-29. DOI: 10.26534/kimika. v28i2.22-29

Scott E. Comparing NAEP, TIMSS, and PISA in Mathematics and Science. Available from https:// nces.ed.gov/timss/pdf/naep_timss_pisa_comp.pdf

Sjöberg L. and Dahlstrand U. Subject matter attributes and study interests in post-secondary education. Higher Educ. 1987; 16 (3), 357-372

So W, Cheng M. Science education in Hong Kong: Opportunities for research and development. Hong Kong Educational Research Association, 2009; 24 (2), 195-229

Spelling M. Helping your child succeed in school. U.S. Department of Education [Internet]. 2005. Available from https://www2.ed.gov/parents/academic/help/succeed/succeed.pdf

Sumintono B. Science education in Malaysia: Challenges in the 21st century. 1st International Seminar on Science Education, Universitas Negeri Yogyakarta (October 2015); 2015 
Sun L. and Bradley K. School computer use and academic performance. Available from http://www. uky.edu/ -kdbrad2/MWE-RA_Letao.pdf

Tizzo MS, Palmes ND. Academic performance of Chemistry majors in selected Chemistry courses: Input for the licensure examination preparation. IAMURE Int J Educ. 2013; 5 (1)

Topçu MS, Erbilgin E, Serkan A. Factors predicting Turkish and Korean students' Science and Mathematics achievement in TIMSS 2011. Eurasia J Math Sci Tech Educ. 2016; 12 (7), 1711-1737

Udoh AO. Learning environment as correlates of Chemistry students' achievement in secondary schools in Akwa Ibom State of Nigeria. Afr Res Rev. 2012; 6(3), 208-217

Visser M, Juan A, Feza N. Home and school resources as predictors of mathematics performance in South Africa. South Afr J Educ. 2015; 35 (1), $1-10$

Wieman C. Science education in the 21 st century using the tools of science to teach science. Forum for the Future of Higher Education [Internet]. 2008. Available from https://net.edu-cause.edu/ir/library/ pdf/ff0814s.pdf

Yüksel M, Geban Ö. A study of the prediction of academic achievement in the Chemistry course. Educ Sci. 2014; 39 (173), 354-365 